\title{
Structure, Conduct and Performance of Maize Marketing in Irewole Local Government Area, Osun State
}

\author{
${ }^{1}$ L. O. Jimoh, ${ }^{1 *}$ O. K. Akintunde, A. L. Kehinde, ${ }^{1 T}$. O. Agboola and ${ }^{2}$ A. A. Alabi \\ ${ }^{1}$ Department of Agricultural Economics and Agribusiness Management, Osun State University, Osogbo, Osun State, Nigeria. \\ 2Department of Agricultural Extension and Rural Development, Osun State University, Osogbo, Osun State, Nigeria \\ [“Corresponding Author: E-mail: olaide.akintunde@uniosun.edu.ng ?: +2348060657304]
}

\section{ABSTRACT}

The study analyzed the marketing of maize in Irewole Local Government Area of Osun State and describes the socio-economic characteristics of maize marketers by determining the marketing margin, marketing cost, markup, operational efficiency as well as constraints faced by maize marketers in the area. Data used for the study were generated through the administration of structured questionnaire. A total of 120 respondents comprising of 40 maize wholesalers and 80 retailers, were randomly sampled from three purposively selected major maize markets. Descriptive statistics, Concentration Ratio, Gini Coefficient and Operational Efficiency Model were the analytical tools adopted for the study. The findings of the study revealed that maize marketing was efficient and profitable; $\$ 900$ and $\$ 1200$ per $100 \mathrm{~kg}$ bag for wholesalers and retailers, respectively in the study area. There also exists variation in marketing cost, marketing margin, marketing profit, and markup for both wholesale and retail maize markets. Gini Coefficients of 0.319 and 0.312 were obtained for wholesaler and retailer, respectively indicating high level of competition in the industry. Major problems facing both wholesalers and retailers are price uncertainty, high perishability of maize and seasonal nature of maize. However, insecurity and high capital requirement are considered as major constraints. It is therefore recommended that the challenges be alleviated to improve efficiency of maize market in the area.

Keywords: Margin, Cost, Markup, Efficiency, Constraints, Corn

\section{INTRODUCTION}

Globally, food insecurity is an increasingly alarming problem. Nigeria global hunger index scores fluctuated substantially in recent years, it tended to increase through 1997 - 2020 period ending at 29.2 index (Food and Agricultural Organization, FAO, 2020). Also in Nigeria, according to FAO (2019), 15 million people $(12.6 \%$ of the population) are undernourished, many people and most households in Nigeria depend on cereals (most especially, maize) as principal source of food and nutrition (Fadina and Barjolle, 2018). Maize is an important food security crop serving as both cash and food crop and recently replacing crops such as sorghum and millet as the most consumed cereal in Nigeria ((Sertoglu et al., 2017). This grain crop is also used for animal feed and has risen to commercial scale where it provides raw materials to many agro-based industries (Iken and Amusa, 2014). Unfortunately, most agricultural programmes and policies in Nigeria focus more on increasing output with little emphasis on marketing strategies (Akanni, 2012). According to Umar et al. (2011), marketing can be defined as a process of bringing together the demand and supply forces irrespective of the market location. The major determining factors of marketing are prices and the different functions performed by the various institutions involved in the activities. Marketing functions in trade activities are the creation of an optimal sales network for effective sale of product including creation of a network of retail and wholesale stores, intermediate warehouses, identification of routes, transportation, loading and unloading supply system (Rustam, 2020). Seasonal analysis of the structure, conduct, and performance (SCP) of markets for staple crops has received relatively little attention in food policy analysis, yet it has important implications for food and nutrition security (Dennis et al., 2019). Market dictates 
how businesses behave (conduct) which ultimately determines the (performance) of the market (Winsih, 2007). Similarly, the distribution along marketing channels preferable for agricultural commodities depends on the degree of marketing margin of the traders (Akanni, 2012).

Domestic food demand in the country has outstripped food supply over the years resulting in wide food deficits leading to large scale food importation (CBN, 2016). The continuous increase in the demand for maize could be attributed to the value of the product and increase in population resulting in product scarcity and soaring market price. The situation is also aggravated by the lack of efficient marketing system, poor marketing performance and inadequate storage facilities and marketing losses. Also, insecurity, bad roads, poor transportation system, high cost of transport, price instability and poor storage infrastructure in market places are major market challenges of maize business. In view of the current challenges facing maize marketing, it is therefore imperative to know how efficiently maize marketing performs in the study area. Therefore, guaranteeing better price to producer, which is also a way to sustain production and ensuring low distribution cost being the goal of an efficient marketing system (Kassali et al., 2018)

Food crop farmers need to be more responsive to market indicators; maize production and marketing being important in the economy of Nigeria. Also, income distribution pattern among maize marketers is a major index in determining the level of economic growth as well knowing the best policy practices that could address the challenges in maize marketing. In view of this, this study specifically (i) described the socio economic characteristics of maize marketers; (ii) Analyzed the structure, conduct and performance of maize marketing; (iii) identifies the constraints facing maize marketing in the study area.

\section{MATERIALS AND METHODS Study Area}

The study was carried out in Irewole Local government of Osun State, Southwest geopolitical zone of Nigeria. Its headquarters are in the town of lkire in the south of the area at latitude $7^{\circ} 21^{\prime} 40^{\prime} \mathrm{N}$ and longitude $4^{\circ} 11^{\prime} 00^{\prime} \mathrm{E}$. The town covers a total land area of $271 \mathrm{~km}^{2}$ with the population of 143,599 according to the 2006 population census. The climate of the area is Savannah type, with two seasons, with the wet season spanning from March to October while the dry season covers late October to March. Each of these seasons is characterized by the influence of the South Westerly wind from the equatorial rain belt. Agriculture is the predominant occupation mostly in the study area. Maize is a common staple food and maize marketing is a common enterprise in markets in the area. The market of maize is also being handled by wholesalers and retailer.

\section{Method of Data Collection and Analytical Tools}

Two-stage Random Sampling procedure was adopted to select maize marketers. The first stage was the purposive selection of three main maize markets in the area because of easy access to maize marketers. The second stage involved the selection of 10 maize wholesalers and 20 maize retailers respectively from each market, making a total of 40 wholesalers and 80 retailers for the study. The primary data collected included quantity (bags) of maize bought, selling price of maize, loading and offloading charges, transportation cost, rent, market tax, depreciation and product losses.

\section{Data Analysis}

Descriptive statistics such as arithmetic mean, standard deviation, frequency distribution and percentage were used for analysis.

\section{Market Structure Analysis}

This was done using the following approaches: 


\section{Nigerian Journal of Basic and Applied Science (December, 2021), 29(2):59-66}

\section{Concentration Ratio}

This parameter measures market structure using the ratio of the two, four and eight largest firm's sales to the total sales of all sampled as follows;

$\mathrm{CR}=\sum \mathrm{i}_{\mathrm{n}} \mathrm{V} \sqrt{\mathrm{S}}$

With $n=2 ; 4$; and 8

$S_{i}=i^{\text {th }}$ largest firm sales

$S=$ total sales of all the firms

The Gini Coefficient: (GC) was used to determine the degree of competition or monopoly in the market. The model is specified as follow; $G C=1-\sum X Y$

Where, $G C=$ Gini Coefficient; $\Sigma=$ Summation; $X$ $=$ percentage distribution of sales; $Y=$ cumulative percentage distribution of sales revenue

\section{Market Conduct Analysis}

This is one of the most important components of a comprehensive market behavior analysis. Market behavior is the behavior of buyers and sellers, strategy or reaction of buyers and sellers individually or in groups in competitive relations or negotiations with other buyers and sellers to achieve the marketing objectives of a market. It assesses competitors' strengths and weaknesses in market place and implements effective strategies to improve competitive advantage.

\author{
Market Performance Analysis \\ a) Marketing Margin \\ $\mathrm{MM}=\mathrm{SP}-\mathrm{BP}$ \\ Where, \\ $\mathrm{MM}=$ Marketing Margin \\ $\mathrm{SP}=$ selling price \\ $\mathrm{BP}=$ buying price \\ b) Marketing Profit (1 bag) \\ Profit $=$ MM $-\mathrm{MC}$ \\ Where, \\ $M C=$ Marketing Cost $=$ cost of transport, \\ handling, marketing charges, tax, shop rent, \\ loading and offloading costs. \\ c) Markup Analysis \\ Mark up $=(S P-B P) \times 100 S P$ \\ d) Operational Efficiency (OE) Analysis \\ $\mathrm{OE} i=$ sales $M C$ (Local efficiency)
}

$\mathrm{OE}=$ OEiOE $0 \times 100$ (Global efficiency)

$\mathrm{OE} 0=$ Most locally efficient firm

\section{RESULTS AND DISCUSSION \\ Socio-economic Characteristics of Respondents}

The results in Table 1 show that $95.8 \%$ of maize marketers in the three markets visited were females. However, findings of Mohammeda et al. (2019) reported male dominance of maize markets in Gombe State, Nigeria. The observed difference probably is attributable to socio-cultural influence of the study areas. Results show that $62.5 \%$ and $68.7 \%$ respectively for wholesalers and retailers were married. Similarly, $75 \%$ and $74 \%$ of wholesalers and retailers, respectively had both primary and secondary education. The results predict the reduction in the cost of hired labour to carry out the task of marketing when family members are engaged in marketing activities and their ability to cope with some challenges of their marketing businesses due to their literacy level. Similar finding was reported by Chirwa (2009) where smallholder maize farmers rely on family labour in marketing.

\section{Respondents Age, Marketing Experience, Household Size and Capital Level}

Results as presented in Table 2 shows that the minimum and maximum age of both wholesalers and retailers ranged between 25 and 65 years while the mean age was 37.50 years. This implies majority of respondents involved in maize marketing are young and still in their active and productive age. The minimum years of marketing experience recorded was 1 year, while household size and level of capital were two persons and $\mathrm{A10,000}$, respectively. The average years of marketing experience, household size and capital level were 13.7 years, 8 persons and $\mathrm{A}$ $355,600.00$, respectively. The results show respondents were not only experienced, but also possess a reasonable level of human and capital fund, a predictor that can accelerate them to high level of success in their businesses. 
Jimoh et al. Structure, Conduct and Performance of Maize Marketing in Irewole...

Table 1: Socioeconomic characteristics of maize marketers $(n=120)$

\begin{tabular}{lcccc}
\hline & \multicolumn{2}{c}{ WHOLESALER } & \multicolumn{2}{c}{ RETAILER } \\
Variable & Frequency & Percentage & Frequency & Percentage \\
\hline Gender & & & & \\
Male & 5 & 12.5 & 0 & 0 \\
Female & 35 & 87.5 & 80 & 100 \\
& & & & \\
Marital Status & & & 55 & 68.7 \\
Married & 25 & 62.5 & 15 & 18.8 \\
Single & 05 & 12.5 & 10 & 12.5 \\
Widowed & 10 & 25.0 & & \\
& & & & \\
Education qualification & 10 & 25.0 & 15 & 31.2 \\
Primary & 10 & 50.0 & 35 & 43.8 \\
Secondary & 20 & 05.0 & 00 & 00.0 \\
Tertiary & 02 & 25.0 & 30 & 37.5 \\
Others & 10 & &
\end{tabular}

Source: Field survey data, 2020

Table 2: Distribution of respondents according to age, marketing experience, household size and capital $(n=120)$

\begin{tabular}{llllll}
\hline VARIABLE & MINIMUM & MAXIMUM & MEAN & STD ERROR & DEV. \\
\hline Age(Years) & 25.0 & 65.0 & 37.5 & 0.89 & 9.85 \\
Marketing exp.(Years) & 1.0 & 50.0 & 3.70 & 0.81 & 18.91 \\
Household size (No.) & 2.0 & 15.0 & 7.6 & 0.53 & 5.81 \\
Capital ('000N) & 10.0 & 8,000 & 355.68 & 1.10 & 888.20 \\
\hline
\end{tabular}

Source: Field survey data, 2020

\section{Market Structure Analysis}

Table 3 shows the 2 -firms concentration ratio (CR2) for wholesalers and retailers were $0.145 \%$ and $0.095 \%$, respectively, while in the case of 4 firms (CR4), $0.269 \%$ and $0.175 \%$ respectively were recorded. The 8-firms' ratio (CR8) of $0.354 \%$ and $0.275 \%$ were estimated for wholesalers and retailers respectively. This is in agreement with findings of Ozor and Nwankwo (2018). This means the concentration ratios of the two marketer groups were low thus at the levels of wholesale and retail, maize marketing is highly competitive. 


\section{Nigerian Journal of Basic and Applied Science (December, 2021), 29(2):59-66}

Table 3: Measure of concentration ratios of maize marketing in the study area

\begin{tabular}{llll}
\hline Concentration ratio & CR2 & CR4 & CR8 \\
\hline Wholesalers & 0.145 & 0.269 & 0.354 \\
Retailers & 0.095 & 0.175 & 0.275 \\
\hline
\end{tabular}

Source: Field survey data, 2020.

\section{Gini Coefficient Analysis}

Results in Tables 4(a) and 4(b) present 0.3190 and 0.312 , respectively as the Gini coefficient values for wholesalers and retailers of maize marketers in the study area. The finding is similar to Ozor and Nwankwo, (2018) in the South
Eastern region of Nigeria. This indicates high level of competition among maize marketers in the area. However, the maize market retailers recorded a lower Gini coefficient than the wholesalers, thereby indicating a greater number of retailers than the wholesalers in the markets.

Table 4(a): Gini Coefficient analysis for wholesalers

\begin{tabular}{lllll}
\hline RANGE MILLIONS & FREQ. & $\%$ & CUM \% & XY \\
\hline $1-2$ & 07 & 0.175 & 0.175 & 0.0306 \\
$2.1-4$ & 21 & 0.525 & 0.700 & 0.3675 \\
$4.1-6$ & 09 & 0.225 & 0.925 & 0.2081 \\
$6.1-8$ & 03 & 0.075 & 1.000 & 0.0750 \\
\hline
\end{tabular}

Source: Field survey data, 2020

$\Sigma X Y($ WS $)=0.6837 ;$ G.C (Wholesaler) $=1$ - 0.6812; G.C $=0.319$

Table 4(b): Gini Coefficient analysis for retailers

\begin{tabular}{lllll}
\hline RANGE (MILLIONS) & FREQ & $\%$ & CUM \% & XY \\
\hline $0.1-0.5$ & 15 & 0.187 & 0.187 & 0.0349 \\
$0.6-1$ & 41 & 0.512 & 0.699 & 0.3578 \\
$1.1-2$ & 23 & 0.287 & 0.986 & 0.2831 \\
$2.1-4$ & 01 & 0.012 & 1.000 & 0.012 \\
\hline
\end{tabular}

Source: Field survey data, 2020

$\Sigma X Y(R T)=0.6878 ; G C$ (Retailer) $=1-0.693 ;$ G.C $=0.312$

\section{Market Conduct in the Study Area}

The maize market survey in the area showed that price is mainly determined by cost and relatively by the market forces of supply and demand. There is no discriminatory pricing, no advertisement or maize branding.

\section{Marketing Channel of Maize in the Study Area}

The marketing channel of maize is the path through which the dry maize product moves from the farmers/producers until it gets to the final consumers. Three channels of maize marketing were identified as follows:

i. Farmers $\rightarrow$ consumers

ii. Farmers $\rightarrow$ speculator $\rightarrow$ consumers

iii. Farmers $\rightarrow$ retailers $\rightarrow$ consumers iv. Farmers $\rightarrow$ local assemblers $\rightarrow$ wholesalers $\rightarrow$ retailers $\rightarrow$ consumer

The first channel indicates movement of maize produce from farmers directly to consumers. This is the most preferred channel by consumers as prices are likely to be cheaper. The second channel indicates movement of maize produce from farmers to consumers through speculators. This is the most unwanted channel by consumers because of likelihood of price increase. The third channel makes product available to consumers through retailers. This is possible because maize, being staple food and grown by many households, they can easily offer part of it for sale in order to gain some price leverage. The longest 
and most commonly used channel is the fourth channel. Here maize produce moves from farmers to local assemblers then to wholesalers. It further moves from wholesalers to retailers and to final consumers. Maize supply chain utilizes the fourth channel in the study area being the most financed channel of all. Ozor and Nwankwo, (2018) reported a similar trend in the South-East of Nigeria where four channels of maize distribution were identified.

\section{Marketing Performance \\ Marketing profit per $100 \mathrm{~kg}$ bag}

As presented in Table 5, a $100 \mathrm{~kg}$ bag of maize is used to estimate profits from maize marketing It can be seen that Wholesalers made profits of A900.00 per $100 \mathrm{~kg}$ bag while retailers' make up to $\$ 1200.00$ per $100 \mathrm{~kg}$ bag. Their respective rates on return on investment $(\mathrm{RNI})$ were 0.11 and 0.14 . This is in agreement with Muhammeda et. al. (2019) who reported positive RNI 0.13 kobo on maize maketing in Gombe, Nigeria. This means for wholesalers, on every naira invested, 0.11 kobo is returned while retailers made 0.14 kobo on every naira invested. Since RNI is positive for both, it can be deduced that maize marketing is lucrative and worth undertaking in the study area. The results further showed that wholesale efficiency was $311.76 \%$ while that of retailing was $246.34 \%$ meaning that value addition through marketing was $11.76 \%$ for wholesalers and $46.34 \%$ for retailers more than the cost incurred in the process of marketing.

Table 5: Marketing margin and income of maize marketing in the area $(\mathrm{A} / 100 \mathrm{Kg})$

\begin{tabular}{lcc}
\hline ITEM & WHOLESALER & RETAILER \\
\hline (a) Buying price (BP) & 7200 & 7720 \\
(b) Marketing Cost(MC) & 425 & 820 \\
(c) Selling price (SP) & 8950 & 9740 \\
(d) Marketing Margin & 1325 & 2020 \\
(MM) & & \\
(e) Profit= MM-MC & 900 & 1200 \\
Rate of return & 0.11 & 0.14 \\
Efficiency & $311.76 \%$ & $246.34 \%$ \\
\hline
\end{tabular}

Operational Efficiency of Maize Marketing in the Study area

Results in Table 6 showed the operational efficiency of wholesalers and retailers. It revealed that $22.5 \%$ and $6.2 \%$ respectively of wholesaler and retailer of maize markets were within operational efficiency of 70 to 80 percent. It can also be seen that majority of both wholesalers and retailers fell within the efficiency range of 80 90 percent. Judging from efficiencies of the wholesalers and retailers, the retailers returned higher operational efficiency than wholesaler, except at range $70-80$ percent where wholesalers had $22.5 \%$ as against $6.5 \%$ for retailers. The result is in line with the findings of Babatunde and Oyatoye, (2005). On the whole, functions of wholesaling and retailing were operationally efficient, meaning that marketing functions were performed at the lowest costs possible in the area. 
Table 6: Operational efficiency analysis

\begin{tabular}{lllll}
\hline \multicolumn{3}{c}{ WHOLESALER } & RETAILER \\
\hline Range & Frequency & Percentage & Frequency & Percentage \\
$\mathbf{7 0 - 8 0}$ & 09 & 22.5 & 05 & 6.2 \\
$\mathbf{8 1 - 9 0}$ & 27 & 67.5 & 61 & 76.3 \\
$\mathbf{9 1 - 1 0 0}$ & 04 & 10.0 & 14 & 17.5 \\
\hline \multicolumn{5}{c}{ Source: Field survey data, 2020 }
\end{tabular}

Markup is the percentage added to the cost of goods to obtain selling price.

Markup $=S P-B P-M C x 100 / S P$

Markup value for Wholesalers $=(8950-$

$7200-425) \times 100 / 8950=14.8 \%$

Markup value for Retailers $=9740-7720-820) x$ $100 / 9740=12.3 \%$. This is Similar to findings by (Obasi et al., 2012) where he discovered that maize marketing in Aba Local Government Area of Nigeria was reasonably priced and profitable. From the above, the estimated markup price for wholesalers and retailers were $14.8 \%$ and $12.3 \%$ respectively. This is a pointer to reasonable pricing of maize in the area, in view of supply coming from far places.

\section{Constraints Faced by Maize Marketers in the Area}

Table 7 presented the results of the distribution of constraints to maize marketing in the study area. From the analysis, it can be seen that the most serious constraint facing wholesalers is inadequate capital $(40 \%)$, followed by insecurity $(25 \%)$ and maize seasonality nature (15\%) Retailers complained inadequate capital as the most serious problem, followed by high rate of perishability of maize due to inefficient storage and preservative mechanism and price uncertainty. In agreement with the result from of this study, Babatunde and Oyatoye, (2005) and Labaris et al. (2014), reported some of the major problems of food marketing and highlighted transportation problem, inadequate market infrastructure, inadequate funding, shortage of processing facilities, seasonality and perishability of food produce and lack of uniform measure and long chain of distributors

Table 7: Constraints of maize marketing faced by marketers in the study area

\begin{tabular}{lcccl}
\hline CONSTRAINTS & \multicolumn{2}{c}{$\begin{array}{c}\text { FREQUENCY } \\
\text { Wholesaler Retailer }\end{array}$} & $\begin{array}{c}\text { PERCENTAGE } \\
\text { Wholesale Retailer }\end{array}$ \\
\hline High cost of maize & 02 & 05 & 5.0 & 6.2 \\
Inadequate Capital & 16 & 30 & 40.0 & 37.5 \\
Maize seasonality nature & 06 & 02 & 15.0 & 2.5 \\
High transportation & 03 & 10 & 7.5 & 12.5 \\
Insecurity & 10 & 05 & 25.0 & 6.2 \\
High rate of perishability & 01 & 15 & 2.5 & 18.8 \\
Price uncertainty & 02 & 13 & 5.0 & 16.3 \\
Total & 40 & 80 & 100.0 & 100.0 \\
\hline
\end{tabular}

Source: Field survey data, 2020

\section{CONCLUSION}

Findings in this study observed that the comparative analysis suggest differences in the market structure of wholesalers and retailers as influenced by the marketing channels of maize in the study area including marketing cost, marketing margin, marketing profit and markup. The concentration ratio, for wholesalers and retailers revealed that the market is perfectly competitive and the business is profitable for both 


\section{Jimoh et al. Structure, Conduct and Performance of Maize Marketing in Irewole...}

wholesalers and retailers. In terms of market efficiency, retailers are more efficient even though the market is optimally priced and operationally efficient. Relevant stakeholders should provide good storage facility like mini-crib, silos warehouses to reduce maize perishability. Traders should be encouraged to create formidable co-operative groups for the purpose of accessing relevant finance and inputs for the continuity and sustainability of their business.

\section{REFERENCES}

Akanni, K.A. (2012). Economics of Marketing of Food Grains in South Western Nigeria. Economía Mexicana nuevaépoca. 21(2):373-390.

Babatunde, R., \& Oyatoye, E. (2005). Food Security and Marketing Problems in Nigeria: The Case of Maize Marketing in Kwara State. Accessed on 17/07/2012.

CBN. (2016). Central Bank of Nigeria Statistical 450 Bulletin, 20. Central Bank of Nigeria, 451 Abuja.

Chirwa, E.W., (2009). Determinants of marketing channels among smallholders' maize farmers in Malawi. Department of Economics, University of Malawi Chancellor College's Working Paper No.2009/03. Retrieved on 06/09/2016

Dennis, O. O., Rosemary, B., \& Bob B. (2019). Structure, Conduct and Performance of Maize Markets in Malawi. The International Food Policy Research Institute, Strategy support Programme, Working Paper 29, August 2019.

Fadina. A. M., \& Barjolle, D. (2018). Farmers' Adaptation Strategies to Climate Change and Their Implications in the Zou Department of South Benin. Environments Journals, 5(15): page no.

Food and Agriculture Organisation, (2020). FAO.Nigeria at a Glance. 2020. Available online: http://www.fao.org/nigeria/fao-innigeria/nigeria-at-a-glance/en/ (accessed on 23 October 2020).

Food and Agricultural Organization (FAO), (2019). FAOSTATDatabase. http:/l apps.fao. org/servlet/xteserviet.
Iken, J. E., \& Amusa, N.A. (2014). Maize research and production in Nigeria. Institute of Agricultural Research and Training (IAR\&T), African Journal of Biotechnology, 3(6): 302-307.

Kassali, R, Girei, A. A., \& Sanu, I. D. (2018). Analysis of Yam Marketing in Akoko North-East Local Government Area of Ondo State, Nigeria.International Journal of Agricultural Marketing, 5(1): 170-177.

Labaris A., Yusuf, K. S., Medugu, N. I., \& Barde, M. M., (2014). Problems of Guinea Corn Marketing in Nasarawa State, Nigeria. International Journal of Science, Environment and Technology, 3(5): 1790 1796.

Mohammeda, S., Sani, R. M., Idi, S., \& Abubakar, N. (2019). Costs and Returns Analysis of Maize Wholesaling in Gombe Metropolis, Nigeria. Journal of Agriculture and Ecology Research International, 2(3)1-9.

Obasi I.O, Majeha RO, Okocha MS. Dried maize marketing in Aba Local Government Area of Abia State, Nigeria: Implication for Employment. A International Conference on Trade, Tourism and Management, Bangkok, Thailand, 2012:153-155.

Ozor, M. U., \& Nwankwo, T. N. (2018) A Comparative Analysis of the Market Structure of Two Varieties of Maize (zea mays) in South-east, Nigeria. International Journal of Agriculture and Forestry, 8(4): 150-154.

Rustam, J. (2020). Effective Use of Marketing Functions in Trade. International Journal on Integrated Education, 3(10): 334251.

Sertoglu, K., Ugural, S. and Bekun, F. V. (2017). The Contribution of Agricultural Sector on Economic Growth of Nigeria, International Journal of Economics and Financial Issues, 7(1): 547-552.

Umar, H. Y., Otitolaiye, J. O., \& Opaluwa, H. I. (). Evaluation of Acacia species (Gum Arabic) Market Structure, Conduct and Performance in Borno State Nigeria." Journal of Agriculture and Social Science, 7(2): 17-20.

Winsih, D.M. (2007). Analysis of Structure, Conduct and Performance of Manufacturing Industry in Indonesia. Essay. Faculty of Economics and Management Bogor Agricultural University Bogor.Jln. Agatis Kampus IPB Dramaga, Bogor 16680 